\title{
Liver Hemangioma
}

National Cancer Institute

\section{Source}

National Cancer Institute. Liver Hemangioma. NCI Thesaurus. Code C3869.

A hemangioma arising from the liver. 